\title{
Jerzy Ząbkowicz
}

Forum Myśli Instytucjonalnej

e-mail: j.zabkowicz@yahoo.com

\section{PROBLEM POZYTYWNEJ DYSKRYMINACJI UNIJNEGO SEKTORA MŚP W SFERZE ZAMÓWIEŃ PUBLICZNYCH W ŚWIETLE PRAWA WTÓRNEGO UE}

\author{
THE PROBLEM OF POSITIVE DISCRIMINATION \\ OF THE EU SME SECTOR IN THE AREA \\ OF PUBLIC PROCUREMENT IN THE LIGHT \\ OF THE EU SECONDARY LEGISLATION
}

DOI: $10.15611 /$ pn.2017.493.10

JEL Classification: H41, H57

\begin{abstract}
Streszczenie: Jednym z celów dokonanej w 2014 r. nowelizacji pakietu dyrektyw z 2004 r. w sprawie zamówień publicznych było zwiększenie udziału sektora MŚP w unijnych procedurach przetargów publicznych. Nowe regulacje miały w tym względzie stanowić odpowiedź na rodzącą się silną tendencję publicznych nabywców do agregacji zamówień w celu uzyskania ekonomii skali - połączoną z trwającą dominacją podmiotów zasiedziałych. W ocenie unijnego prawodawcy groziło to znacznym ograniczeniem dostępu sektora MŚP do rynku zamówień publicznych. Przeciwdziałając temu, wprowadzono m.in. instrumenty służące obniżaniu progu dostępności do zamówień publicznych poprzez dzielenie dużych zamówień na części. W artykule przedstawiono proces modyfikacji podejścia instytucji unijnych do kwestii udziału sektora MŚP w rynku zamówień publicznych. Ma on stanowić przyczynek do rozważań nad problemem praktycznej skuteczności przepisów dotyczących podziału zamówień publicznych na części.
\end{abstract}

Słowa kluczowe: zamówienia publiczne, sektor MŚP, środki pozytywnej dyskryminacji.

Summary: One of the goals of the 2014 amendment to the 2004 Public Procurement Directives was to increase the share of the SME sector in the EU public procurement procedures. This new regulation was in response to the emerging strong tendency of public purchasers to aggregate orders for economies of scale - coupled with the ongoing dominance of incumbents. In the assessment of the EU legislator this threatened a significant reduction of the SME sector's access to the public procurement market. Counteracting such a situation, legislation aimed at lowering the threshold for access to public procurement by dividing large orders into parts was introduced. This article aims to present a process of modifying the approach of the EU institutions to the participation of the SME sector in the public procurement market. At the same time it is intended to contribute to the discussion on the issue of the practical effectiveness of the rules governing the division of public contracts into lots.

Keywords: public procurement, SME sector, measures of positive discrimination. 


\section{Wstęp}

Od wielu lat sektor MŚP sygnalizuje istnienie wielu barier ograniczających jego dostęp do rynku zamówień publicznych. Generalnie problem ten przypisywany jest ograniczeniom w potencjale organizacyjnym i finansowym, jakim dysponują mniejsze podmioty gospodarcze, ale też, niestety, podejściu instytucji zamawiających, które niejednokrotnie swoimi działaniami (lub brakiem działań) owe obiektywnie istniejące ograniczenia ,przekształcają" ${ }^{1} \mathrm{~W}$ bariery jeszcze bardziej utrudniające lub wręcz eliminujące udział MŚP w postępowaniach o zamówienie publiczne - zamiast je obniżać. W tym sensie źródeł problemu można też (i należy) poszukiwać w obowiązujących w danym czasie przepisach prawa wtórnego, powinny one bowiem przeciwdziałać takim zachowaniom, zapewniając transparentność i równe szanse wszystkim uczestnikom procedur przetargowych.

$\mathrm{Na}$ skutek ograniczonego potencjału organizacyjno-finansowego podmiotom z sektora MŚP zainteresowanym rynkiem zamówień publicznych często brakuje czasu i środków (w tym wykwalifikowanego personelu) na pozyskanie niezbędnych informacji, profesjonalne zapoznanie się z procedurą przetargową oraz przygotowanie oferty i towarzyszącej jej dokumentacji [Bovis 1998; KE 2008a, s. 5]². Towarzyszą temu zarzuty ze strony MŚP o nieproporcjonalnie wysokie wymagania zamawiających w zakresie poziomu kwalifikacji, certyfikacji oraz gwarancji finansowych - niejednokrotnie tak sformułowane, iż budzą uzasadnione przypuszczenia, że ich celem jest wyeliminowanie części oferentów. Długie terminy płatności typowe dla tej kategorii kontraktów również stanowią znaczące obciążenie dla płynności finansowej mniejszych przedsiębiorstw [Intrum Justicia 2017].

Dla tych podmiotów z sektora MŚP, które mimo napotkania wymienionych barier podejmują decyzję o ubieganiu się o przyznanie zamówienia publicznego, oznacza to zazwyczaj nieproporcjonalnie wysokie koszty udziału w procedurach przetargowych (w porównaniu z dużymi przedsiębiorstwami) oraz nadmierne obciążenie administracyjne [Fee, Erridge, Hennigan 2002, s. 326-334; KE 2008a, s. 5; Nicholas, Fruhmann 2014, s. 335-336]. Jednak jeszcze poważniejszą barierę stanowi duża wartość kontraktów, będąca swoistym katalizatorem możliwości udziału MŚP w rynku zamówień publicznych - ta bowiem nie tylko utrudnia, ale często wręcz uniemożliwia im podjęcie się realizacji zadania [Morand 2003; Nicholas, Fruhmann 2014, s. 336-337].

Celem niniejszego opracowania jest próba oceny dokonującej się zmiany podejścia unijnego prawodawcy do kwestii tworzenia sektorowi MŚP warunków skutecz-

\footnotetext{
${ }^{1}$ Słowo „przekształcają” należy rozumieć zarówno jako zaniechanie działań, które pomogłyby obniżyć tego typu bariery, jak i wykorzystywanie wspomnianych ograniczeń w celu eliminowania części oferentów na korzyść operatorów zasiedziałych, od dawna współpracujących z zamawiającym.

${ }^{2}$ Problem asymetrii informacyjnej w kontekście udziału MŚP w postępowaniach o zamówienia publiczne został poruszony w: [Mishory 2013, s. 20-24].
} 
nego konkurowania na rynku zamówień publicznych. Szczególnie istotny wydaje się wymiar praktyczny dokonywanych w tym zakresie modyfikacji prawa wtórnego UE, przez co należy rozumieć kwestię realnego oddziaływania przepisów unijnych na decyzje podejmowane na poziomie państw członkowskich. Tak sformułowany cel kieruje nas przede wszystkim do źródeł pierwotnych - dokumentów UE, jednak nie tylko do aktów prawa twardego i miękkiego, ale również do raportów analizujących powyższy problem.

Szerszym tłem dla kwestii poruszanych w niniejszym opracowaniu jest problem barier ograniczających możliwość stworzenia otoczenia instytucjonalnego zapewniającego w pełni efektywne działanie rynku zamówień publicznych. Rynek ten tradycyjnie już stanowi przedmiot gry sił politycznych i grup interesu (zarówno na poziomie krajowym, jak i UE), stąd stale aktualne pozostaje pytanie nie tylko o wewnętrzną spójność systemu unijnych norm formalnych, ale - w równym stopniu o interakcje zachodzące między instytucjami formalnymi i nieformalnymi, wpływające na skuteczność oddziaływania bodźców i sankcji tworzonych przez te pierwsze.

\section{Sektor MŚP w postanowieniach generacji dyrektyw z 2004 r.}

Wartość udzielanego zamówienia publicznego jest jednym z tych elementów, które mogą się okazać barierą nie do pokonania dla mikro-, małego lub średniego przedsiębiorstwa. Stąd też naturalne staje się postawienie już na wstępie pytania, czy i w jakim stopniu unijny prawodawca odniósł się do tego wcale nie nowego problemu w generacji dyrektyw z 2004 r. w sprawie zamówień publicznych33.

Okazuje się, że przyjęto podejście de facto dyskryminujące sektor MŚP na rynku dużych zamówień publicznych - pozycjonując zaliczane do tej grupy podmioty jako podwykonawców. Zawarte w preambułach obu dyrektyw zalecenie uwzględnienia przepisów mających zachęcić małe i średnie przedsiębiorstwa do udziału w procedurach przetargowych przypisywało im właściwie tylko taką rolę4. Jednak i same postanowienia dotyczące podwykonawstwa w zamówieniach na roboty budowlane, dostawy i usługi (w tym w sektorach regulowanych) ograniczono wyłącznie do kwestii określenia odpowiedzialności głównego wykonawcy za działania podwykonawców 5 .

${ }^{3} \mathrm{Na}$ wymienioną generację dyrektyw złożyły się: dyrektywa Parlamentu Europejskiego i Rady 2004/18/WE z dnia 31 marca 2004 r. w sprawie koordynacji procedur udzielania zamówień publicznych na roboty budowlane, dostawy i usługi, Dz.U. L 134 z 30.04.2004, oraz dyrektywa Parlamentu Europejskiego i Rady 2004/17/WE z dnia 31 marca 2004 r. koordynująca procedury udzielania zamówień przez podmioty działające w sektorach gospodarki wodnej, energetyki, transportu i usług pocztowych, Dz.U. L 134 z 30.4.2004.

${ }^{4}$ Motyw 32 w preambule dyrektywy 2004/18/WE. Identyczne podejście odnajdziemy w motywie 43 preambuly dyrektywy 2004/17/WE.

${ }^{5}$ Tamże, odpowiednio art. 25 i art. 37. 
Pośrednie odniesienie do obecności MŚP w sferze zamówień publicznych pojawia się w stanowiącym novum tytule III dyrektywy 2004/18/WE określającym reguły dotyczące koncesji na roboty budowlane. Instytucji zamawiającej przyznane zostało prawo do wymagania, ,aby koncesjonariusz udzielił stronom trzecim zamówień o wartości stanowiącej co najmniej 30\% całkowitej wartości robót budowlanych będących przedmiotem koncesji na roboty budowlane"6. Choć w kontekście podwykonawstwa nie pojawiła się tu w ogóle kategoria MŚP, jednak można przyjąć, że zastosowanie przez instytucję zamawiającą cytowanego wymogu powinno okazać się korzystne dla przedsiębiorstw o mniejszym potencjale zainteresowanych rynkiem zamówień publicznych.

Potencjalnie dodatkową szansę na zwiększenie zdolności konkurowania z dużymi podmiotami gospodarczymi otwierały firmom z sektora MŚP postanowienia dyrektyw z 2004 r., umożliwiające przystępowanie do procedur przetargowych jako grupa wykonawców łącząca w tym celu posiadane zdolności operacyjne i zasoby ${ }^{7}$. Artykuł 4 ust. 2 dyrektywy 2004/18/WE ${ }^{8}$ stanowił przy tym, że ,instytucje zamawiające nie mogą wymagać, aby grupy wykonawców przybierały określoną formę prawną”, jednak zamieszczona w tym samym artykule „furtka” przyznawała zamawiającemu prawo do zastosowania takiego wymogu ,w zakresie, w jakim zmiana ta niezbędna jest do zadowalającej realizacji zamówienia”. W praktyce dawało mu to pełną swobodę decydowania co do wykorzystania tego typu bariery prawno-organizacyjnej, bardzo skutecznej w przypadku podmiotów z sektora MŚP ${ }^{9}$. Tak więc stawiany przez prawo wspólnotowe wymóg, aby zamawiający akceptowali nieujętą w odpowiednie formy prawne współpracę mniejszych podmiotów [KE 2008a, s. 8], mógł być traktowany jako co najwyżej niezobowiązujące do niczego zalecenie ${ }^{10}$.

Oceniając generację dyrektyw z 2004 r. w sprawie zamówień publicznych, można zaryzykować twierdzenie, że występujące ograniczenie roli sektora MŚP do podwykonawstwa wynikało w dużej mierze z faktu, iż unijny prawodawca nie dostrzegał jeszcze tego sektora jako istotnego stymulatora mogącego zwiększyć efektywność funkcjonowania całej sfery zamówień publicznych. Rzecz jasna, konieczne byłoby najpierw stworzenie ku temu odpowiednich warunków. Warto jednak pamiętać, że omawiany pakiet dyrektyw procedowano w okresie nieodległym od czasów euforii

${ }^{6}$ Art. 60 dyrektywy 2004/18/WE. Podobne rozwiązanie zostało zastosowane w dyrektywie 2009/81/WE w sprawie udzielania zamówień w dziedzinach obronności i bezpieczeństwa (art. 21).

${ }^{7}$ Art. 47 ust. 2 i 3, art. 48 ust. 3 i 4, art. 52 ust. 1 akapit 3 dyrektywy 2004/18/WE oraz art. 53 ust. 4 i 5 , art. 54 ust. 5 i 6 dyrektywy 2004/17/WE.

${ }^{8}$ A także, odpowiednio, art. 11 ust. 2 dyrektywy 2004/17/WE.

${ }^{9}$ Przeprowadzone badania wskazują na niechęć (lub ograniczoną zdolność) podmiotów z sektora MŚP do wspólnego przystępowania do procedur zamówień publicznych. W 2001 r. jedynie 13\% z wymienionej kategorii przedsiębiorstw, które pozyskały tego typu kontrakty, regularnie współpracowało w trakcie przetargów z innymi podmiotami (41\% - okazjonalnie) [EIM 2004, s. 19].

${ }_{10}$ Nawet w przypadku dopuszczenia do współpracy między MŚP instytucja zamawiająca była w stanie bezkarnie zablokować taką możliwość, np. nie publikując wstępnego ogłoszenia informacyjnego, które dałoby oferentom z sektora MŚP dostateczną ilość czasu na przygotowanie wspólnej oferty [KE 2008a, s. 8]. 
na światowych giełdach i rodzącej się wiary w przełom, do jakiego miało dojść za sprawą tzw. nowej gospodarki. W centrum uwagi znajdowało się coś zupełnie innego niż MŚP - przyszłość gospodarki wiązano przede wszystkim z powstawaniem sektorów tzw. wysokiej techniki. Te z kolei wymagały odpowiedniego poziomu nakładów na badania naukowe i wdrożenia, stąd uwaga decydentów koncentrowała się na podmiotach o wysokiej wartości marki - zwykle utożsamianych z korporacjami transnarodowymi, traktowanymi jako motor napędowy oczekiwanego rozwoju gospodarczego. Przesunęło to MŚP na dalszą pozycję w hierarchii priorytetów legislacyjnych, zwłaszcza w początkowym okresie.

Można wręcz odnieść wrażenie, że nie widziano dostatecznych powodów, żeby przypisać wymienionemu sektorowi rolę kreatywnego ,akcjonariusza” dokonujących się procesów globalizacyjnych i ich spodziewanego przyszłego przebiegu. Tym samym w ówczesnym podejściu zabrakło, jak się wydaje, spojrzenia na sektor MŚP jako na odrębną, spójną kategorię podmiotów gospodarczych wymagającą poświęcenia jej w tym względzie szczególnej uwagi, włącznie z wdrożeniem instrumentów wspierających ją w pokonywaniu barier rynkowych.

Co więcej, w owym czasie pośrednim zagrożeniem dla oferentów dysponujących ograniczonym potencjałem staje się narastające zainteresowanie scentralizowanymi technikami zakupów. W pakiecie dyrektyw z 2004 r. fakt ten znalazł wyraźne odzwierciedlenie m.in. we wprowadzonej do przepisów wspólnotowych definicji centralnych jednostek zakupujących (central purchasing bodies) obsługujących instytucje zamawiające ${ }^{11}$. Przyjęte spojrzenie na techniki umożliwiające zakupy dużych wolumenów eksponuje punkt widzenia interesów ekonomicznych zamawiającego - identyfikowane są one jako instrument zwiększenia konkurencji i usprawnienia procesu dokonywania zakupów publicznych. W zawartym w preambułach obu dyrektyw wezwaniu do zdefiniowania warunków zapewniających przestrzeganie zasad niedyskryminacji i równego traktowania brakuje jakiegokolwiek odniesienia do potencjalnego pogorszenia pozycji przetargowej sektora MŚP ${ }^{12}$.

\section{Wpływ dyrektyw z 2004 r. na udział MŚP w zamówieniach publicznych}

Począwszy od 2008 r., coraz powszechniej artykułowana jest opinia, że pozostawienie regulacji unijnych w dotychczasowym kształcie nie pozwala na wykorzystanie rzeczywistego potencjału MŚP w postępowaniach o zamówienia publiczne. Czy

${ }^{11} \mathrm{~W}$ tym okresie centralne jednostki zakupujące funkcjonowały już w wielu państwach członkowskich (CONSIP we Włoszech, Bundesbeschaffungsamt w Niemczech, OGC buying.solutions w Wielkiej Brytanii itd.), z czasem stając się coraz poważniejszymi graczami na rynku zamówień publicznych - np. zamówienia austriackiego Bundesbeschaffung GmbH (BBG) wyniosły w 2014 r. ok. 1,2 mld EUR [KE 2015, s. 61]. Celem obu dyrektyw było zatem rozpoczęcie procesu harmonizacji zasad ich funkcjonowania na poziomie unijnym [Beuter 2005, s. 8].

${ }^{12}$ Preambuły dyrektyw 2004/18/WE i 2004/17/WE - odpowiednio motywy 15 i 23. 
oznacza to zarazem, że w okresie po wejściu w życie pakietu z 2004 r. udział tego sektora $\mathrm{w}$ realizacji zamówień objętych przepisami prawa wtórnego UE nie odpowiadał jego ogólnej pozycji w gospodarce unijnej?

W pełni spójne dane z okresu poprzedzającego obowiązywanie omawianej generacji dyrektyw odnoszą się jedynie do kategorii zamówień publicznych o wartości powyżej progów wyznaczonych przez te dyrektywy, tj. wymagających publikacji w suplemencie do Dziennika Urzędowego UE (Tenders Electronic Daily, TED) ${ }^{13}$. Wynika z nich, że w latach 2002-2005 na podmioty należące do unijnego sektora MŚP przypadło, odpowiednio, 59\%, 63\%, 65\% i 64\% ogólnej liczby przyznanych pojedynczych kontraktów należących do powyższej kategorii [GHK i Technopolis 2014, s. 54]. Zarazem jednak udział sektora w łącznej wartości tego typu kontraktów był znacznie niższy - wynosząc w kolejnych latach 33\%, 39\%, 35\% i 42\% Dość wyraźny wzrost udziału, jaki miał miejsce w 2005 r., był nie tyle efektem oddziaływania postanowień dyrektyw z 2004 r., ile dołączenia do UE nowych państw członkowskich. Na sektor MŚP przypadło w nich 59\% wartości przyznanych ponadprogowych kontraktów, podczas gdy w UE-15 - jedynie 39\% ${ }^{15}$. Co więcej, odnotowany w 2005 r. udział MŚP w skali całej Unii na poziomie 42\% łącznej wartości kontraktów trudno uznać za sukces, skoro już w 2001 r. wyniósł on 43\% [GHK i Technopolis 2014, s. 20].

Dane z raportu GHK wskazują, że w kolejnych latach (2006-2008) na unijny sektor MŚP przypadało średniorocznie około 60\% ogólnej liczby zamówień spośród opublikowanych w TED, jednak udział podmiotów z wymienionego sektora w łącznej ich wartości oscylował w granicach od 31 do 38\% [GHK 2010, s. 21]. Biorąc pod uwagę analizowany okres, uzyskujemy średnią na poziomie zaledwie $34 \%$, co oznacza nadal trwające znaczne niedowartościowanie w stosunku do roli, jaką MŚP odgrywały w tym czasie w gospodarce unijnej - pamiętajmy bowiem, że dostarczały one wówczas około 52\% jej łącznego obrotu.

Wyraźna jest przy tym zależność między wielkością przedsiębiorstw a efektami ich aktywności przetargowej. Na mikroprzedsiębiorstwa przypadało średniorocznie zaledwie 6\% wartości udzielonych ponadprogowych zamówień publicznych, podczas gdy ich ogólny udział w realnej gospodarce UE wynosił w tym okresie 17\%. $\mathrm{Z}$ kolei w przypadku małych przedsiębiorstw proporcje te kształtowały się, odpowiednio, na poziomie $11 \%$ i $16 \%$, co również oznaczało niedowartościowanie w sferze zamówień publicznych, jednak znacznie mniejsze. Średnie przedsiębiorstwa miały już, jak na to wskazują statystyki unijne, wystarczający potencjał do w miarę

\footnotetext{
${ }^{13}$ A więc objętych przepisami unijnych dyrektyw w sprawie udzielania zamówień publicznych. W przypadku zamówień publicznych o wartości poniżej progów określonych w dyrektywach (i zarazem nie opublikowanych w TED) statystyki są niekompletne i niejednolite.

${ }^{14}$ Wszystkie podane liczby nie uwzględniają udziału przedsiębiorstw z sektora MŚP uczestniczących w realizacji kontraktów jako podwykonawcy.

${ }^{15}$ Należy również pamiętać, że wyznaczonym terminem wykonania obu dyrektyw był dopiero 31 stycznia 2006 r., stąd ich wdrażanie było w 2005 roku dopiero w trakcie.
} 
skutecznego konkurowania - w każdym razie na tyle, aby osiągnąć pod tym względem poziom bliski równowagi (odpowiednio 17\% i 19\%). Jednak szczególnie niepokojące wydają się te statystyki z lat 2006-2008, z których wynika, że o ile sektor MŚP potrafił konkurować w sytuacji, gdy kryterium wyboru stanowiła cena (udział w wartości udzielonych zamówień na poziomie, kolejno, 38\%, 41\% i 43\%), o tyle coraz bardziej forsowane kryterium oferty najkorzystniejszej ekonomicznie okazało się istotną barierą dla MŚP (odpowiednio udział na poziomie 28\%, 28\% i 37\% wartości ponadprogowych zamówień publicznych) [GHK 2010, s. 32]. W większości przypadków mniejsze podmioty były zatem w stanie konkurować głównie ceną, ale już nie innymi parametrami oferty.

Trudno również nie zwrócić uwagi na znaczne różnice między poszczególnymi krajami co do udziału sektora MŚP w wartości zamówień publicznych z tego okresu - począwszy od 79\% w Bułgarii przez (przykładowo) 44\% we Francji, kończąc na $22 \%$ w Hiszpanii i Portugalii oraz $17 \%$ w Republice Czeskiej. Istniejące różnice zdają się potwierdzać tezę o słabym wpływie dyrektyw unijnych z 2004 r. na ujednolicenie podejścia instytucji krajowych wobec kwestii udziału sektora MŚP w sferze zamówień publicznych, konkretnie zaś - podjęcia praktycznych działań na rzecz obniżenia barier, które tradycyjnie już utrudniają mniejszym firmom skuteczne konkurowanie z dużymi podmiotami gospodarczymi. Wystarczy odnotować, że w latach 2006-2008 jedynie w czterech państwach członkowskich udział sektora MŚP w udzielonych ponadprogowych zamówieniach publicznych był większy niż jego rola w krajowej gospodarce ${ }^{16}$ [GHK 2010, s. 27].

Relatywnie niska łączna wartość ponadprogowych zamówień publicznych pozyskanych przez unijny sektor MŚP w latach 2006-2008 ${ }^{17}$ - przy znacznie większym udziale w liczbie kontraktów - umożliwia przyjęcie założenia, że w wielu przypadkach główną (i nie do pokonania) barierą mogła się okazać sama wielkość udzielanego zamówienia, przekraczająca ograniczone możliwości realizacyjne niewielkiego przedsiębiorstwa ${ }^{18}$. Wyraźnie to zresztą potwierdzają szczegółowe statystyki z raportu GHK z 2010 r., opracowanego na zamówienie Dyrekcji Generalnej ds. Przedsiębiorstw i Przemysłu (DG Enterprise and Industry $)^{19}$.

W omawianym okresie mediana wartości ponadprogowych kontraktów opublikowanych w suplemencie do Dziennika Urzędowego UE (Tenders Electronic Daily,

${ }^{16}$ W krańcowym przypadku Portugalii i Hiszpanii różnica na niekorzyść udziału MŚP w wartości udzielonych zamówień publicznych (w stosunku do udziału w gospodarce) wyniosła odpowiednio 46 i $42 \%$.

${ }^{17}$ A więc już pod rządami pakietu z 2004 roku.

${ }^{18}$ Nie ulega wątpliwości, że w przypadku zamówień publicznych o większej wartości dodatkowymi istotnymi barierami dla MŚP były niejednokrotnie nadmierne wymagania formalne (proceduralne) w tym wysokie koszty udziału w przetargu (wadium, gwarancje bankowe itd.), konieczność posiadania personelu o odpowiednich kwalifikacjach, referencje itd.

${ }^{19}$ Obecnie Dyrekcja Generalna ds. Rynku Wewnętrznego, Przemysłu, Przedsiębiorczości i MŚP (DG Internal Market, Industry Entrepreneurship and SMEs, w skrócie: DG Growth). 
TED) oscylowała w granicach od 366 do 391 tys. euro, co stanowiło zauważalny wzrost w stosunku do lat poprzedzających (rok 2004 - 324 tys. euro; 2005 - 335 tys. euro $)^{20}$. Można zaryzykować wniosek, że generacja dyrektyw z 2004 r. nie dostarczyła wystarczająco silnego bodźca (przy braku innych instrumentów), aby zahamować trend wzrostowy mediany wartości zawartych kontraktów. Okazał się on szczególnie szybki w przypadku kontraktów na roboty budowlane (wzrost z poziomu 330 tys. euro w 2002 r. do 928 tys. euro w 2008 r.). W zakresie dostaw i usług także odnotowany został wzrost, choć nie tak znaczący (odpowiednio z 297 tys. euro do 350 tys. euro oraz z 330 tys. euro do 364 tys. euro).

Istotną informacją z perspektywy możliwości pozyskiwania kontraktów przez sektor MŚP jest to, czy były one dzielone na części i na jakim poziomie znajdowała się mediana wartości tych partii (lots), które stanowiły autonomiczne elementy w ramach danej procedury ubiegania się o udzielenie zamówienia publicznego. W opisanej sytuacji rozwiązanie w postaci podziału zamówień wydaje się bowiem jedynym „prostym” sposobem poszerzenia dostępu mniejszych podmiotów do tego rynku.

Ograniczając się do danych odnoszących się do dużych unijnych gospodarek, można zauważyć, że podziały zamówień na części miały miejsce, jednak w stosunkowo ograniczonym zakresie, szczególnie w niektórych krajach. W latach 2006-2008 w przypadku zamówień ponadprogowych sfinalizowanych przez instytucje zamawiające $\mathrm{w}$ Niemczech jedynie $14 \% \mathrm{z}$ nich zostało uprzednio podzielone, we Włoszech - 18\%, w Wielkiej Brytanii - 24\%, we Francji zaś-39\% ${ }^{21}$. Chociaż wpływ podziału na części na zwiększenie dostępu do mniejszych kontraktów był zauważalny, jednak, jak można przypuszczać, w wielu państwach członkowskich z całego sektora MŚP korzystały na tym jedynie średnie przedsiębiorstwa - ale już nie małe lub mikro, które nadal musiały się zadowolić głównie rolą podwykonawcy ${ }^{22}$. Co więcej, niejednokrotnie duże zamówienia publiczne - tyle, że podzielone czasami na dziesiątki części - i tak w całości padały łupem jednego zasiedziałego operatora o uprzywilejowanej czy wręcz quasi-monopolistycznej pozycji na danym rynku.

Dane statystyczne z raportu GHK z 2010 r. były dla Komisji Europejskiej wyraźnym sygnałem o negatywnym wpływie rosnącej średniej wartości ogłaszanych w TED zamówień publicznych na zdolność sektora MŚP do konkurowania o ich pozyskanie w roli samodzielnych wykonawców. Wynikało z nich, że próg dostępności do zamówień publicznych, powyżej którego udział MŚP w ich realizacji zaczyna stopniowo (i coraz wyraźniej) maleć, znajduje się mniej więcej na poziomie 300 tys.

${ }^{20}$ Wszystkie wartości podane w raporcie GHK są estymacjami.

${ }^{21}$ Skalę zamykały: z jednej strony Republika Czeska - 7\%, z drugiej zaś Cypr - 47\% ogółu ponadprogowych zamówień publicznych. Zob. [GHK 2010, wykres 3.24].

${ }^{22}$ Wystarczy wskazać przypadek Danii, w której w 2008 r. mediana zagregowanej wartości ponadprogowych kontraktów publicznych wyniosła 802 tys. euro, pojedynczych kontraktów zaś (części) - 510 tys. euro. Na przykład dla Wielkiej Brytanii te mediany wyniosły, odpowiednio, 628 i 329 tys. euro, dla Włoch - 786 i 240 tys. euro, Niemiec - 340 i 193 tys. euro, a dla Francji - 293 i 66 tys. euro. Różnice są więc istotne, nadal jednak, z wyjątkiem Francji, mamy do czynienia z dużymi kontraktami. 
euro wartości jednostkowego kontraktu. Co najmniej 60\% łącznej wartości ponadprogowych kontraktów nieprzekraczających tej kwoty trafiło w latach 2006-2008 do sektora MŚP (co można ocenić jako satysfakcjonujący wynik w odniesieniu do ich udziału w gospodarce unijnej) - jednak już w przypadku zamówień publicznych wartych jednostkowo powyżej $5 \mathrm{mln}$ euro udział ten ograniczał się do zaledwie 21-29\% ich łącznej wartości [GHK 2010, s. 32-33].

\section{Globalny kryzys finansowy a postrzeganie roli MŚP w sferze zamówień publicznych}

W ocenie Komisji Europejskiej zawartej w komunikacie z czerwca 2008 r. „UE w sposób zdecydowany umieściła MŚP w centrum strategii lizbońskiej na rzecz wzrostu gospodarczego i zatrudnienia, szczególnie od 2005 r. poprzez wykorzystanie podejścia partnerskiego" [KE 2008b, s. 2] 23. Jak się jednak wydaje, w wymiarze legislacyjnym faktyczna zmiana w postrzeganiu tego sektora jako cennego gracza na rynku zamówień publicznych zaczęła następować znacznie później, w związku z podejmowanymi przez instytucje unijne kolejnymi próbami reakcji na niespotykaną wcześniej skalę problemów, wobec których stanęła cała gospodarka UE.

Do kluczowych wyzwań zaliczono przeprowadzenie ,inteligentnej konsolidacji budżetowej na rzecz osiągnięcia długotrwałego wzrostu" [KE 2010, s. 29], mającej służyć uzyskaniu „nowoczesnej” struktury wydatków publicznych i poprawy ich jakości. W praktyce, w warunkach istniejących deficytów budżetowych i rosnącego zadłużenia sektora finansów publicznych państw członkowskich, jednym z priorytetów stało się zwiększenie efektywności wydatków w sferze publicznej, realizowanych drogą procedur udzielania zamówień publicznych. To zaś, jak uznano, można w znacznej mierze osiągnąć poprzez działania stymulujące szerokie zainteresowanie ubieganiem się o przyznanie owych kontraktów. Inaczej mówiąc, założono, że poszerzenie bazy potencjalnych dostawców spowoduje po stronie podażowej rosnącą presję konkurencyjną na rynku zamówień publicznych [KE 2011a, s. 30].

Główną, niewykorzystaną wcześniej rezerwę stanowiły w tym względzie podmioty z sektora MŚP [KE 2008a, s. 2]. Zmiana podejścia wobec nich, „zauważenie” ich potencjału było zarazem argumentem przeciwko wielokrotnie podnoszonym zarzutom o ignorowanie postulatu równouprawnienia w dostępie do zamówień pu-

${ }^{23} \mathrm{~W} 2006$ r., a więc jeszcze przed rozpoczęciem globalnego kryzysu, o ,uwolnienie potencjału gospodarczego - zwłaszcza MŚP” apelowała w konkluzjach prezydencji Rada Europejska na swoim posiedzeniu w Brukseli w dniach 23-24 marca 2006 r. [RE 2006, s. 9-11]. W dokumencie tym brak jednak bezpośredniego odniesienia do problemów, jakie napotyka sektor MŚP na rynku zamówień publicznych. Postulat podjęcia działań na rzecz zapewnienia MŚP lepszego dostępu do tego rynku pojawia się w komunikacie Komisji KOM(2007) 592 [KWE 2007, s. 7-8]. W opinii w sprawie tego komunikatu, pochodzącej z października 2008 r., Europejski Komitet Ekonomiczno-Społeczny, oceniając sytuację, poczuł się w obowiązku stwierdzić, że nadal ,zbyt łatwo jest ignorować aspekt MŚP w kontekście zamówień publicznych” [EKES 2008, ppkt 4.2]. Zob. także [KWE 2005]. 
blicznych, zgłaszanego przez sektor grupujący 23 mln mikro-, małych i średnich podmiotów gospodarczych, stanowiących ok. 99\% ogólnej liczby przedsiębiorstw w UE i zapewniających $75 \mathrm{mln}$ miejsc pracy. Podmioty te już od dawna wskazywały na istnienie trudnych do pokonania barier $\mathrm{w}$ dostępie do zamówień publicznych, szczególnie o większej jednostkowej wartości. Wynikało to zarówno z braku dostatecznego potencjału do ich pozyskania, jak i dużej atrakcyjności takich kontraktów dla silniejszych, większych konkurentów, z powodzeniem blokujących słabszym podmiotom dostęp do tej części unijnego rynku zamówień publicznych.

Generacja dyrektyw z 2004 r. de facto nie zaoferowała sektorowi MŚP żadnych instrumentów mogących skutecznie wpłynąć na państwa członkowskie w kierunku stworzenia przez nie odpowiednich warunków prawnych dla znaczącego zaistnienia mniejszych podmiotów gospodarczych w roli samodzielnych wykonawców kontraktów o większej wartości. Dopiero w ogłoszonym w 2008 r. Europejskim kodeksie najlepszych praktyk ułatwiających dostęp MŚP do zamówień publicznych Komisja Europejska skierowała do państw członkowskich wyraźny sygnał, stwierdzając, że „bardziej przejrzyste i sprzyjające konkurencji praktyki w dziedzinie zamówień publicznych pozwolą MŚP uwolnić ich potencjał wzrostu i innowacyjności z korzystnym skutkiem dla gospodarki europejskiej”. W jej ocenie dokument miał spełnić dwa konkretne zadania: „1) dostarczyć [...] ogólnych wytycznych dotyczących sposobu stosowania ram prawnych UE, tak by poprawić udział MŚP w procedurach udzielania zamówień, oraz 2) zwrócić uwagę na te krajowe przepisy i praktyki, które ułatwiają dostęp MŚP do zamówień publicznych" [KE 2008a, s. 2]. Komisja wskazała zatem ,właściwe" metody rozwiązania problemu - dokonała tego jednak w sposób, który nie wykroczył, podobnie jak wcześniejsze działania, poza ramy prawa miękkiego. Jest to zresztą wyraźnie zaznaczone w samym dokumencie. $\mathrm{KE}$ artykułuje w nim oczekiwanie, że kodeks „pomoże instytucjom zamawiającym opracować [służące temu - JZ] 'strategie', 'programy' lub 'plany działania'[...]" [KE 2008a, s. 3] ${ }^{24}$. W sumie ma to jednoznaczny wydźwięk - dla instytucji zamawiających kodeks nie ma mocy wiążącej, tym bardziej że jest to „zaledwie” dokument roboczy służb Komisji.

Podejście zaprezentowane przez KE zarówno w Kodeksie najlepszych praktyk jak i w komunikacie „Najpierw myśl na małą skalę” wyraźnie podąża za sugestiami uczestników przeprowadzonych przez nią konsultacji. Kwintesencję stanowi postulat respondentów, zgodnie z którym „do ułatwienia dostępu MŚP do zamówień publicznych najbardziej potrzebne są nie zmiany legislacyjne w dyrektywach dotyczących zamówień publicznych, lecz zmiana kultury instytucji zamawiających w zakresie udzielania zamówień" [KE 2008a, s. 5]. O ile trudno się nie zgodzić z drugą częścią tego wniosku (o zmianie kultury), o tyle w świetle ówczesnych prak-

${ }^{24}$ Jego wydźwięk jeszcze bardziej osłabia zawarta w nim zwyczajowa formuła: „Niniejszy 'Kodeks najlepszych praktyk' jest dokumentem o charakterze orientacyjnym [wytł. JZ] [...] i nie należy go uznawać za wiążący dla tejże instytucji w jakikolwiek sposób" [KE 2008a, s. 3]. 
tyk tychże instytucji wobec sektora MŚP sugestia pozostania przy unijnym prawie zamówień publicznych z 2004 r. (w części odnoszącej się do wymienionego sektora) wydaje się wychodzić głównie naprzeciw partykularnym interesom zamawiających i związanych z nimi operatorów zasiedziałych.

\section{Zmiana podejścia wobec obecności MŚP na rynku zamówień publicznych. Generacja dyrektyw z 2014 r.}

W dokumencie roboczym z 2008 r. służby Komisji przyznały otwarcie, że „tylko nieliczne państwa członkowskie przyjęły i wdrożyły ogólnokrajową 'strategię', 'program' lub 'plan działania', którego celem byłoby [...] zwiększenie dostępu MŚP do zamówień publicznych [...]”, zaś „,zdecydowana większość [...] zgłosiła podjęcie w ostatnich latach jedynie działan sporadycznych lub o ograniczonym zakresie" [KE 2008a, s. 6]. Tym samym Komisja podważyła de facto sens dalszego stosowania wyłącznie miękkich instrumentów oddziaływania na władze publiczne i instytucje zamawiające. W świetle fiaska wcześniejszych wysiłków proponowane przez $\mathrm{KE}$,przyspieszenie tempa wymiany praktyk pomiędzy odpowiednimi instytucjami w państwach członkowskich [...]" oraz ,podjęcie wzmożonych starań w celu wymiany doświadczeń płynących z poprzednich działań ze wszystkimi zainteresowanymi stronami" [KE 2008a, s. 6] sprawia wrażenie swoistej kapitulacji wobec oporu lobby przeciwstawiającego się „twardym” regulacjom na poziomie unijnym.

Sygnałem do rozpoczęcia dyskusji na temat wprowadzenia bardziej szczegółowych instrumentów i mechanizmów pozwalających zachować „odpowiednią równowagę między umożliwieniem silniejszej agregacji popytu w sektorach strategicznych i nieograniczaniem konkurencji na rynkach zamówieniowych (ze szkodą zwłaszcza dla MŚP), np. poprzez dzielenie zamówień na części” stała się dopiero Zielona księga ze stycznia 2011 r. [KE 2011a, s. 26] ${ }^{25}$. W dokumencie tym Komisja po raz pierwszy bezpośrednio odniosła się do padających sugestii wprowadzenia środków pozytywnej dyskryminacji na rzecz podmiotów z sektora MŚP. Jednak wskazany instrument w postaci zastrzegania z góry części zamówień wyłącznie dla nich został jednoznacznie odrzucony jako działanie sprzeczne z unijną zasadą równego traktowania oferentów ${ }^{26}$.

Bardziej przychylne stanowisko KE zajęła w stosunku do opcji zastosowania wewnętrznych środków administracyjnych, np. ustalania wartości docelowych dotyczących udziału MŚP w całości udzielanych zamówień. Podobnie jak w przypadku wcześniej stosowanych instrumentów rozwiązanie to widziane było jako „miękkie”

\footnotetext{
${ }^{25}$ Jeszcze w 2010 r. Parlament Europejski, wzywając Komisję do podjęcia działań zwiększających dostęp podmiotów z sektora MŚP do zamówień publicznych, odnosił się do ich udziału w rynku jedynie jako podwykonawców, a nie głównych wykonawców (np. realizujących kontrakty podzielone na części) [PE 2010, s. 43-44].

${ }^{26}$ Tego typu środki są stosowane przez wiele krajów spoza UE.
} 
oddziaływanie w postaci dostarczenia instytucjom zamawiającym ,zachęt do jak najlepszego wykorzystania dostępnych instrumentów na rzecz prowadzenia przyjaznej dla MŚP polityki zamówieniowej" [KE 2011a, s. 32]. Jako kwestię otwartą Komisja pozostawiła opcję polegającą na rozszerzeniu na zamówienia publiczne narzędzia już wcześniej wprowadzonego do dyrektywy 2004/18/WE - ale tylko w odniesieniu do koncesji na roboty budowlane - polegającego na umożliwieniu instytucjom zamawiającym nakładania na zwycięskiego oferenta obowiązku zlecania osobom trzecim realizacji części zamówienia o określonej wartości.

Zawarte w Zielonej księdze z 2011 r. konkluzje wskazujące na konieczność przeprowadzenia rewizji unijnego systemu zamówień publicznych poprzez unowocześnienie istniejących narzędzi i metod (co potwierdziły późniejsze konsultacje) znalazły swój finał w postaci wniosków Komisji dotyczących modyfikacji przepisów w sprawie zamówień publicznych z grudnia 2011 r. [KE 2011b; KE 2011c]. Końcowym tego efektem jest aktualnie obowiązująca generacja dyrektyw z 2014 r. ${ }^{27}$, w znacznie szerszym zakresie wprowadzająca instrumenty mogące wpływać - zarówno bezpośrednio, jak i pośrednio - na skalę obecności podmiotów z sektora MŚP na unijnym rynku zamówień publicznych.

W dyrektywie klasycznej 2014/24/UE sygnałem zasadniczej zmiany podejścia unijnego prawodawcy jest sprawiający dość ,techniczne” wrażenie nowo wprowadzony art. 46, zatytułowany „Podział zamówień na części””28. Generalnie, stosowanie go ma charakter fakultatywny, co wyraźnie wynika z ust. 1 mówiącego, że, ,instytucje zamawiające mogą [wytł. JZ] postanowić o udzieleniu zamówienia w oddzielnych częściach; mogą [wytł. JZ] też określić wielkość i przedmiot takich zamówień". Przewidzianą możliwość nałożenia rygoru wymagalności takiego podziału (art. 46 ust. 4) pozostawiono do decyzji władz publicznych państw członkowskich.

Wprowadzonym modyfikacjom wyraźnie jednak przyświecał zamiar znacznie poważniejszy niż tylko uelastycznienie procedur przetargowych. Sygnalizuje to już preambuła, w której zwrócono uwagę na coraz silniej zauważalną tendencję publicznych nabywców do agregacji zapotrzebowania w celu uzyskania ekonomii skali, w tym niższych cen i kosztów transakcyjnych. W ocenie unijnego prawodawcy pociąga to za sobą m.in. groźbę rosnącej koncentracji (centralizacji) zakupów mogącej

${ }^{27}$ Składają się na nią: dyrektywa Parlamentu Europejskiego i Rady 2014/24/UE z dnia 26 lutego 2014 r. w sprawie zamówień publicznych, Dz.U. L 94 z 28.03.2014 oraz dyrektywa Parlamentu Europejskiego i Rady 2014/25/UE z dnia 26 lutego 2014 r. w sprawie udzielania zamówień przez podmioty działające w sektorach gospodarki wodnej, energetyki, transportu i usług pocztowych, Dz.U. L 94 z 28.03.2014.

${ }^{28}$ Odpowiednio art. 65 dyrektywy 2014/25/UE. Ze względu na to, że rozwiązania dotyczące podziału zamówień na części przyjęte w dyrektywie klasycznej 2014/24/UE zastosowano, mutatis mutandis, również w dyrektywie sektorowej 2014/25/UE (z wyjątkiem wymogu uzasadniania przez podmioty zamawiające decyzji dotyczącej niedzielenia umów na mniejsze części), druga z wymienionych dyrektyw nie będzie oddzielnie omawiana. Opisane regulacje nie znajdują natomiast, ze zrozumiałych względów, odzwierciedlenia w zawartości trzeciej dyrektywy należącej do pakietu z 2014 roku (dyrektywa 2014/23/UE w sprawie udzielania koncesji). 
prowadzić do odczuwalnego ograniczenia możliwości dostępu do rynku zamówień publicznych dla mikro-, małych i średnich podmiotów ${ }^{29}$. Przeciwdziałając temu, należy, jego zdaniem, zachęcać instytucje zamawiające do dzielenia dużych zamówień na częśsici ${ }^{30}$.

Dodatkowo uznano, iż w przypadku zamówień publicznych objętych postanowieniami dyrektyw z 2014 r. państwom członkowskim trzeba otworzyć możliwość wywarcia presji na zamawiających poprzez wprowadzenie obowiązku uzasadnienia przez instytucję zamawiającą decyzji o niedokonaniu takiego podziału bądź wręcz uczynienia takiego podziału obowiązkowym ${ }^{31}$. Warto przy okazji zwrócić uwagę na to, że z wniosku Komisji COM(2011) 896 z 2011 r. dotyczącego dyrektywy w sprawie zamówień publicznych wynika, że za duże zamówienie publiczne (podlegające przepisom o podziale na części) uznała ona każde, którego wartość była nie mniejsza niż 500 tys. euro [KE 2011b, art. 44] $]^{32}$.

Trudno nie zauważyć, że wprowadzone w 2014 r. modyfikacje obowiązujących uprzednio rozwiązań prawnych wnoszą zarazem istotne novum do relacji między zamawiającymi i instytucjami unijnymi. Te ostatnie, szczególnie Komisja Europejska, stanęły w obliczu konieczności znacznego przewartościowania swojego podejścia wobec niektórych działań podejmowanych przez instytucje zamawiające. Wcześniej w codziennej praktyce przyjmowano a priori założenie, że przejawiane przez zamawiających skłonności do dzielenia zamówień publicznych na części stanowią nic innego jak próbę uniknięcia obowiązku podporządkowania się przepisom unijnego prawa wtórnego, to zaś spotykało się ze zdecydowanym przeciwdziałaniem [Ząbkowicz 2017, s. 184-191]. Znowelizowane postanowienia dyrektyw wymagają, aby dotychczasową z góry zadekretowaną nieufność wobec tego typu posunięć zastąpiło nie tylko przyzwolenie, ale wręcz wyraźne oczekiwanie dokonywania takich podziałów (rzecz jasna, przeprowadzonych w sposób ekonomicznie zasadny i transparentny). W bardzo otwarty sposób - szczególnie w strategii Europa 2020, ale nie tylko - uzasadniane jest to chęcią silniejszego wciągnięcia MŚP w proces modernizacji gospodarki UE.

Analizując zagadnienie w odniesieniu do realnej gospodarki, można za najważniejszą uznać odpowiedź na pytanie, w jakim stopniu przepisy dotyczące podzia-

\footnotetext{
${ }^{29}$ Zob. motyw 59 preambuły dyrektywy 2014/24/UE.

${ }^{30}$ Wielkość i przedmiot tych części - jednorodnych lub niejednorodnych - powinny być dowolnie określane przez instytucję zamawiającą.

${ }^{31}$ Rzecz jasna pod warunkiem, że nie jest on mniej korzystnym rozwiązaniem od udzielenia zamówienia w całości lub w postaci zbiorów części. Zob. motywy 78-79 preambuły dyrektywy 2014/24/UE oraz motywy 87-88 preambuly dyrektywy 2014/25/UE.

${ }^{32} \mathrm{~W}$ wersji dyrektywy przyjętej przez Parlament i Radę ta część postanowienia została pominięta. W przeciwieństwie do wyżej wymienionego projektu w analogicznym wniosku dotyczącym dyrektywy Parlamentu Europejskiego i Rady w sprawie udzielania zamówień przez podmioty działające w sektorach gospodarki wodnej, energetyki, transportu i usług pocztowych, $\operatorname{COM(2011)~} 895$ final - 2011/0439 (COD) brak było odniesienia do minimalnej wartości dużego zamówienia (art. 59).
} 
łu zamówień na części, wprowadzone dyrektywami 2014/24/UE i 2014/25/UE, są w stanie uruchomić krajowe mechanizmy wzmacniania obecności sektora MŚP na rynku zamówień publicznych. Konkretnie zaś - czy działania władz publicznych państw członkowskich ograniczą się do już przeprowadzonej transpozycji obu dyrektyw, czy też będą miały wszelkie cechy autentycznej ich implementacji? ${ }^{33}$ Należy bowiem zdawać sobie sprawę $\mathrm{z}$ tego, iż w wielu przypadkach sama transpozycja nie jest w stanie spowodować odczuwalnego ograniczenia zjawisk patologicznych. Pamiętajmy, że już generacja dyrektyw z 2004 r. pozwalała na udzielanie zamówień $\mathrm{w}$ formie odrębnych części ${ }^{34}$. Wbrew intencji unijnego prawodawcy efektem dokonywanych podziałów były niejednokrotnie sytuacje, w których wszystkie części zamówienia i tak trafiały do operatora zasiedziałego, mimo że nie wykraczały poza możliwości wykonawcze mniejszych podmiotów gospodarczych.

Tego typu dyskryminujące działania ograniczające konkurencję w sferze zamówień publicznych nie zostały pozostawione bez reakcji w zmodyfikowanych przepisach z 2014 r. odnoszących się do kwestii podziału zamówień na części. Dają one instytucjom zamawiającym ${ }^{35}$ prawo do ograniczenia liczby części zamówienia, które mogą zostać udzielone jednemu oferentowi ${ }^{36}$. Warunkiem jest, z jednej strony, określenie w ogłoszeniu o zamówieniu lub w zaproszeniu do potwierdzenia zamówienia maksymalnej liczby takich części, z drugiej zaś wskazanie w dokumentach zamówienia obiektywnych i niedyskryminacyjnych kryteriów lub zasad służących ustaleniu - przy przekroczeniu tej liczby - które części zostaną finalnie udzielone zwycięskiemu oferentowi ${ }^{37}$.

Czy jednak fakultatywny instrument w postaci prawa do ograniczenia liczby części zamówienia, które mogą zostać udzielone jednemu oferentowi jest w stanie skutecznie zwiększyć konkurencję, ograniczając dominację podmiotów dysponujących największą siłą przetargową - i tym samym wzmocnić pozycję słabszych uczestników postępowań o udzielenie zamówienia publicznego? Generalnie budzi to duże wątpliwości.

Zacznijmy od zwrócenia uwagi na to, że siła oddziaływania takiego rozwiązania zależy bezpośrednio od stopnia transparentności prowadzonego postępowania. Gdy jest ono w pełni przejrzyste i obiektywne, z ekonomicznego punktu widzenia zastosowanie tego typu ,ślepego" instrumentu może się okazać wręcz szkodliwe dla

\footnotetext{
${ }^{33}$ Niestety, oba te pojęcia są często mylone bądź wręcz traktowane jako substytuty.

${ }^{34}$ Zob. art. 9 ust. 5 dyrektywy 2004/18/WE i art. 17 ust. 6 lit. a) dyrektywy 2004/17/WE.

${ }^{35}$ Jeszcze raz wypada przypomnieć, że w przypadku poruszonej w tekście problematyki kwestie odnoszące się do kategorii podmiotów określonych jako instytucje zamawiające (w rozumieniu dyrektywy klasycznej 2014/24/UE) w przypadku dyrektywy sektorowej 2014/25/UE rozciągają się na szerszą kategorię identyfikowaną jako podmioty zamawiające.

${ }^{36} \mathrm{~W}$ odniesieniu do koncesji EKES był od początku przeciwnikiem przepisu ograniczającego liczbę części koncesji, jakie mogą być przedmiotem oferty lub zostać przyznane. Komitet uważał, że przepis ten jest zbyt skomplikowany i należy go usunąć z wniosku [EKES 2012, pkt 4.25].

${ }^{37}$ Art. 46 ust. 2 akapit 2 dyrektywy 2014/24/UE i, odpowiednio, art. 65 ust. 2 dyrektywy 2014/25/UE.
} 
wyniku przetargu i interesu zamawiającego. Te części danego zamówienia, które nie zostaną przyznane zwycięskiemu oferentowi jedynie z powodu przekroczenia przez niego maksymalnej dopuszczalnej ich liczby, będą powierzone podmiotom, które zaproponowały mniej korzystne warunki finansowe lub jakościowe. Stąd, nawet jeżeli przyjmiemy, że pojawi się pozytywny (?) efekt w postaci swoistej redystrybucji jednostkowych kontraktów między oferentami - powodujący (być może) zwiększenie liczby wykonawców - odbędzie się to kosztem większych wydatków ze strony instytucji zamawiającej lub gorszych parametrów realizacji zamówienia.

$\mathrm{Z}$ założenia, użycie dostarczonego przez dyrektywę instrumentu w postaci „ogranicznika” ilościowego - uruchamiając mechanizm blokujący przejęcie nieograniczonej liczby części zamówienia przez oferenta korzystającego z nienależnej przewagi konkurencyjnej - powinno chronić interesy słabszych uczestników postępowań o zamówienie publiczne. $\mathrm{Z}$ takim zagrożeniem mamy do czynienia w przypadku, gdy pojawiają się uzasadnione wątpliwości co do pełnej transparentności uruchamianej procedury. Jeżeli rzeczywiście miałoby dojść do preferowania któregokolwiek z oferentów, wówczas, właściwie automatycznie, oznacza to brak motywacji u zamawiającego do wykorzystania instrumentu w sposób przewidziany przez unijnego prawodawcę. Zatem w przypadku istnienia nieformalnych uzgodnień między stronami postępowania - co, mówiąc wprost, w niektórych państwach członkowskich UE jest bardziej regułą niż wyjątkiem - instrument zapewne nie będzie w ogóle użyty. Nawet jeżeli dojdzie do wprowadzenia go do procedury, jego parametry mogą zostać tak dopasowane do potrzeb, żeby w praktyce jedynie stwarzać pozory skuteczności.

Podsumujmy. Instytucja zamawiająca zachowująca się w sposób transparentny - co oznacza neutralny stosunek wobec wszystkich uczestników procedury - wykorzystując $w$ procedurze przetargowej fakultatywny instrument w postaci prawa do ograniczenia liczby części zamówienia, które mogą zostać udzielone jednemu oferentowi, w pewnym stopniu działa przeciw własnemu interesowi. Być może będzie zmuszona odrzucić część najlepszych (ale, niestety, „nadliczbowych”) ofert. Z kolei zamawiający, który wbrew zasadom preferuje określonego oferenta, prawdopodobnie w ogóle powyższego instrumentu nie zastosuje, jest on bowiem jedynie zalecany. Co prawda dyrektywy z 2014 r. dają władzom publicznym państw członkowskich prawo do ustanowienia obowiązku udzielania zamówień w formie oddzielnych części - oznacza to jednak otwartą konfrontację z wpływowym lobby instytucji zamawiających i operatorów zasiedziałych.

\section{Zakończenie}

Czas, jaki upłynął od wejścia w życie generacji dyrektyw z 2014 r., nie daje jeszcze, jak się wydaje, wystarczających podstaw do jednoznacznej oceny ich faktycznej skuteczności. Niektóre sygnały nie pozwalają jednak na zbytni optymizm co do osiągnięcia jednego z głównych celów, jakim miało być zwiększenie konkurencyjności 
postępowań poprzez poszerzenie bazy potencjalnych dostawców (w tym, szczególnie, o podmioty z sektora MŚP). Przykładowo, z kolejnych sprawozdań Prezesa UZP za 2015 r. i 2016 r. wynika, że w przeprowadzonych w tym okresie w Polsce postępowaniach ogłoszonych w Biuletynie Zamówień Publicznych (BZP) największą grupę (39\%) nadal stanowiły zamówienia, w których wykonawcy składali tylko jedną ofertę (podczas gdy w 2014 r. - 38\%, 2013 r. - 39\%, 2012 r. - 40\%) [UZP 2017, s. 45]. W przypadku postępowań publikowanych w TED (ponadprogowych) również nie odnotowano w tym względzie istotnego postępu (2015 r. - 43\%, 2014 i 2013 r. - 44\%, 2012 r. - 47\% zamówień) [UZP 2016, s. 35-37] ${ }^{38}$. Warto jednocześnie odnotować fakt, że dane opublikowane w BZP wskazują na trwającą stagnację w zakresie średniej liczby ofert składanych w prowadzonych w Polsce postępowaniach o wartości poniżej progów UE. W 2016 r. wyniosła ona 2,87, co wręcz stanowiło niewielki regres w stosunku do lat poprzedzających $(2015$ r. $-2,90,2014$ r. $-2,89,2013$ r. - 2,96) [UZP 2017, s. 144] ${ }^{39}$.

Wcześniejsze doświadczenia w zakresie efektów dzielenia zamówień na części nakazują przy tym ostrożność w wyciąganiu wniosków, szczególnie gdy analizy jako podstawę przyjmują wyłącznie ,suche” dane statystyczne dotyczące takich podziałów i obowiązujący stan prawny, bez uwzględnienia skutków oddziaływania utrwalonych zwyczajów i relacji panujących na rynku zamówień publicznych w danym państwie członkowskim ${ }^{40}$. Niestety, jako negatywny przykład z przeszłości wskazywane jest w tym względzie funkcjonowanie sfery zamówień publicznych w Polsce.

Jak wynika ze wspomnianego wcześniej raportu GHK z 2010 r., podczas gdy mediana zagregowanej wartości kontraktów ponadprogowych wyniosła dla Polski w 2008 r. około 313 tys. euro, mediana wartości pojedynczego kontraktu (części zamówienia publicznego) kształtowała się na rekordowo niskim poziomie 14 tys. euro, zdecydowanie najniższym w całej $U^{41}$. Równie istotne jest to, że aż 38\% ogólnej liczby ponadprogowych zamówień publicznych zostało w Polsce podzielonych na co najmniej dwie części - co na tle większości państw członkowskich było wysokim

${ }^{38}$ W sprawozdaniu Prezesa UZP za 2016 r. nie wyodrębniono, jako oddzielnej kategorii, statystyk na temat liczby ofert złożonych w postępowaniach ponadprogowych (wymagających publikacji w TED).

${ }^{39} \mathrm{~W}$ świetle powyższych statystyk - jak również danych za lata 2013-2016 o malejącej łącznej wartości i liczbie zamówień udzielonych z wykorzystaniem procedur określonych w Pzp - ewentualny zwiększony dostęp podmiotów z sektora MŚP do rynku zamówień publicznych musiałby się odbyć kosztem udziału w nim dużych przedsiębiorstw (w tym podmiotów zasiedziałych, o dominującej pozycji rynkowej). Istniejące dane nie dają podstaw do twierdzenia, że nastąpiło istotne wzmocnienie pozycji MŚP jako samodzielnych wykonawców zamówień publicznych.

${ }^{40}$ Za przykład może służyć niemiecki rynek zamówień publicznych, gdzie rozbudowane regulacje prawne nie są w stanie zapewnić odpowiednio sprzyjających warunków funkcjonowania sektorowi MŚP. Zob. [Sarter, Fuchs, Sack 2014].

${ }^{41} \mathrm{Na}$ drugim krańcu skali lokowały się: Dania z medianą na poziomie 510 tys. euro, Irlandia - 363 tys. euro, Holandia - 330 tys. euro i Wielka Brytania - 329 tys. euro. Zob. [GHK 2010, s. 35]. 
udziałem (wystarczy porównać z krańcowymi przykładami Republiki Czeskiej czy Austrii, gdzie podziałowi poddano zaledwie 7-8\% kontraktów ponadprogowych).

Tymczasem, przyglądając się danym dotyczącym udziału sektora MŚP w łącznej wartości pozyskanych ponadprogowych kontraktów, łatwo można zauważyć, iż należał on wówczas w Polsce do najniższych w UE - w latach 2006-2008 osiągnął zaledwie 30\% (podczas gdy np. w Bułgarii aż 79\%, na Węgrzech i Słowacji-47\%). Daje to podstawy do stwierdzenia, że w licznych przypadkach duże zamówienia publiczne - chociaż podzielone niejednokrotnie na dziesiątki części - i tak pozostawały poza zasięgiem mikro-, małych i średnich przedsiębiorstw. Dzięki dokonanym podziałom ich potencjał stawał się co prawda wystarczający do realizacji jednostkowych kontraktów, jednak wbrew oczekiwaniom nie wzmocniło to ich relatywnie słabej pozycji w otaczającym je środowisku gospodarczym na tyle, aby poprzez procedurę przetargową mogły skutecznie konkurować z ,argumentami” dominujących, zasiedziałych operatorów, nadal dzielących między siebie zamówienia uznane przez nich za atrakcyjne dzięki dużej łącznej wartości.

Istnieją tym samym uzasadnione obawy, że zmodyfikowane unijne przepisy w sprawie zamówień publicznych nie dokonają w powyższym zakresie spodziewanego przełomu. Oznacza to, że nadal - mimo wysiłków unijnego prawodawcy na rzecz tworzenia spójnego, efektywnego systemu norm formalnych - będziemy mieli do czynienia z silnym, destrukcyjnym oddziaływaniem instytucji nieformalnych, osłabiających skuteczność instrumentów wprowadzonych w ramach generacji dyrektyw z 2014 r., mających ułatwić dostęp MŚP do rynku zamówień publicznych.

\section{Literatura}

Beuter R., 2005, European Public Procurement Reform: Main Innovations in the Public Sector Directive - A Preliminary Assessment, EIPASCOPE 2005/3.

Bovis C., 1998, The regulation of public procurement as a key element of european law, European Law Journal, vol. 4, no. 2.

EIM, 2004, SMEs' access to public procurement contracts. Executive summary, EIM Business and Policy Research, Zoetermeer, March 22.

EKES, 2008, Opinia Europejskiego Komitetu Ekonomiczno-Społecznego w sprawie komunikatu Komisji do Rady, Parlamentu Europejskiego, Europejskiego Komitetu Ekonomiczno-Społecznego i Komitetu Regionów „Małe i średnie przedsiębiorstwa - kwestią kluczową dla zapewnienia wzrostu gospodarczego i zatrudnienia. Przegląd śródokresowy nowoczesnej polityki w zakresie MŚP”, KOM(2007) 592 wersja ostateczna, 2009/C 100/01, Dz.U. UE C 100 z 30.04.2009.

EKES, 2012, Opinia Europejskiego Komitetu Ekonomiczno-Społecznego w sprawie wniosku dotyczącego dyrektywy Parlamentu Europejskiego i Rady w sprawie udzielania zamówień przez podmioty działające w sektorach gospodarki wodnej, energetyki, transportu i usług pocztowych $\operatorname{COM}(2011)$ 895 final - 2011/0439 (COD), wniosku dotyczącego dyrektywy Parlamentu Europejskiego i Rady w sprawie zamówień publicznych COM(2011) 896 final - 2011/0438 (COD), wniosku dotyczącego dyrektywy Parlamentu Europejskiego i Rady w sprawie udzielania koncesji COM(2011) 897 final - 2011/0437 (COD), 2012/C 191/16, Dz.U. UE C 191 z 29.06.2012. 
Fee R., Erridge A., Hennigan S., 2002, SMEs and government purchasing in Northern Ireland: Problems and opportunities, European Business Review, vol. 14, no. 5.

GHK, 2010, Evaluation of SMES'Access to Public Procurement Markets in the EU. Final Report, Ref. Ares(2016)52545 - 06/01/2016.

GHK i Technopolis, 2014, Evaluation of SMEs'Access to Public Procurement Markets in the EU, Final Report, Ref. Ares(2014)75984 - 15/01/2014.

Intrum Justicia, 2017, European Payment Reports, https://www.intrum.com/en/about-us/publications/ european-payment-report/ (25.06.2017).

KE, 2008a, Europejski kodeks najlepszych praktyk ułatwiajacych dostęp MŚP do zamówień publicznych, Dokument roboczy służb Komisji, SEC(2008)2193, Bruksela, 25.06.2008.

KE, 2008b, Najpierw myśl na mata skalę. Program 'Small Business Act' dla Europy, Komunikat Komisji do Rady, Parlamentu Europejskiego, Europejskiego Komitetu Ekonomiczno-Społecznego i Komitetu Regionów, KOM(2008) 394 wersja ostateczna, Bruksela, 25.06.2008.

KE, 2010, Europa 2020. Strategia na rzecz inteligentnego i zrównoważonego rozwoju sprzyjajacego właczeniu społecznemu, Komunikat Komisji do Rady, Parlamentu Europejskiego, Europejskiego Komitetu Ekonomiczno-Społecznego i Komitetu Regionów, KOM(2010) 2020 wersja ostateczna, Bruksela, 3.03.2010.

KE, 2011a, Zielona księga w sprawie modernizacji zamówień publicznych. W kierunku zwiększenia skuteczności europejskiego rynku zamówień, KOM(2011) 15 wersja ostateczna, Bruksela, 27.01.2011.

KE, 2011b, Wniosek dotyczący dyrektywy Parlamentu Europejskiego i Rady w sprawie zamówień publicznych, KOM(2011) 896 wersja ostateczna - 2011/0438 (COD), Bruksela, 20.12.2011.

KE, 2011c, Wniosek dotyczący dyrektywy Parlamentu Europejskiego i Rady w sprawie udzielania zamówień przez podmioty działające w sektorach gospodarki wodnej, energetyki, transportu i usług pocztowych, KOM(2011) 895 wersja ostateczna - 2011/0439 (COD), Bruksela, 20.12.2011.

KE, 2015, Study on "Strategic use of public procurement in promoting green, social and innovation policies", Final Report, DG GROW, Framework Contract NMARKT/2011/023/B2/ST/FC for Evaluation, Monitoring and Impact Assessment of Internal Market DG Activities.

KWE, 2005, Wdrażanie wspólnotowego programu lizbońskiego. Nowoczesna polityka wzrostu i zatrudnienia dla matych i średnich przedsiębiorstw, Komunikat Komisji do Rady, Parlamentu Europejskiego, Europejskiego Komitetu Ekonomiczno-Społecznego i Komitetu Regionów, KOM(2005) 551 wersja ostateczna, Bruksela, 10.11.2005.

KWE, 2007, Mate i średnie przedsiębiorstwa - kwestia kluczowa dla zapewnienia wzrostu gospodarczego i zatrudnienia. Przegląd śródokresowy nowoczesnej polityki w zakresie MŚP, Komunikat Komisji do Rady, Parlamentu Europejskiego, Europejskiego Komitetu Ekonomiczno-Społecznego i Komitetu Regionów, KOM(2007) 592 wersja ostateczna, Bruksela, 4.10.2007.

Mishory E., 2013, Leveling Asymmetry: The Information-Leveling Model of Transparency in Government Procurement, Government Procurement Seminar, The George Washington University Law School, December 22.

Morand P.H., 2003, SMEs and Public Procurement Policy, "Review of Economic Design", No. 8.

Nicholas C., Fruhmann M., 2014, Small and Medium-Sized Enterprises policies in public procurement: Time for a rethink?, Journal of Public Procurement, vol. 14, issue 3.

PE, 2010, Rezolucja Parlamentu Europejskiego z dnia 18 maja 2010 r. w sprawie zmian w procedurze udzielania zamówień publicznych, 2009/2175(INI), P7_TA(2010)0173, Dz.U. UE C 161 E/38.

RE, 2006, Posiedzenie Rady Europejskiej w Brukseli, 23-24 marca 2006 r., Konkluzje prezydencji, 7775/06, Bruksela, 24.03.2006.

Sarter E., Fuchs S., Sack D., 2014, SME-friendly public procurement in Germany? Legal strategies and political challenges, Hans Böckler Stiftung, Working Paper Series 'Comparative Governance', Working Paper, no. 2. 
UZP, 2016, Sprawozdanie Prezesa Urzędu Zamówień Publicznych o funkcjonowaniu systemu zamówień publicznych w 2015 r., UZP, Warszawa, czerwiec.

UZP, 2017, Sprawozdanie Prezesa Urzędu Zamówień Publicznych o funkcjonowaniu systemu zamówień publicznych w 2016 r., UZP, Warszawa, czerwiec.

Ząbkowicz J., 2017, Rynkowe ustugi użyteczności publicznej w Unii Europejskiej. W poszukiwaniu konsensu i pewności prawnej, Wydawnictwo C.H. Beck, Warszawa.

\section{Akty prawne}

Dyrektywa Parlamentu Europejskiego i Rady 2004/17/WE z dnia 31 marca 2004 r. koordynująca procedury udzielania zamówień przez podmioty działające w sektorach gospodarki wodnej, energetyki, transportu i usług pocztowych, Dz.U. L 134 z 30.4.2004.

Dyrektywa Parlamentu Europejskiego i Rady 2004/18/WE z dnia 31 marca 2004 r. w sprawie koordynacji procedur udzielania zamówień publicznych na roboty budowlane, dostawy i usługi, Dz.U. L 134 z 30.04.2004.

Dyrektywa Parlamentu Europejskiego i Rady 2014/24/UE z dnia 26 lutego 2014 r. w sprawie zamówień publicznych, Dz.U. L 94 z 28.03.2014.

Dyrektywa Parlamentu Europejskiego i Rady 2014/25/UE z dnia 26 lutego 2014 r. w sprawie udzielania zamówień przez podmioty działające w sektorach gospodarki wodnej, energetyki, transportu i usług pocztowych, Dz.U. L 94 z 28.03.2014. 